\title{
A zinc metalloprotease inhibitor, Inh, from the insect pathogen Photorhabdus Iuminescens
}

\author{
Michèle Valens, Anne-Cécile Broutelle, Mélanie Lefebvre \\ and Mark A. Blight
}

Author for correspondence: Mark A. Blight. Tel: +33 16915 8168. Fax: +33 169156334 . e-mail:mark.blight@igmors.u-psud.fr

Institut de Génétique et Microbiologie, Laboratoire de Pathogenèse Comparée, CNRS UMR 8621, Bâtiment 360, Université Paris XI, 91405 Orsay Cedex, France

\begin{abstract}
The entomopathogen Photorhabdus luminescens secretes many proteins during the late stages of insect larvae infection and during in vitro laboratory culture. The authors have previously characterized and purified a $55 \mathrm{kDa}$ zinc metalloprotease, PrtA, from culture supernatants of $P$. luminescens. PrtA is secreted via a classical type I secretory pathway and is encoded within the operon prtA-inh-prtBCD. The 405 bp inh gene encodes a 14.8 kDa pre-protein that is translocated to the periplasm by the classical signal-peptide-dependent sec pathway, yielding the mature $11.9 \mathrm{kDa}$ inhibitor Inh. Inh is a specific inhibitor of the protease PrtA. This study describes the purification of Inh and the initial characterization of its in vitro protease inhibition properties.
\end{abstract}

Keywords: protease inhibitor, entomopathogen, protein purification

\section{INTRODUCTION}

Pathogenic bacteria employ many virulence factors for the invasion, colonization and maintenance of infection within a host organism. An aspect of virulence that has been studied extensively involves the modulation of host matrix metalloprotease (MMP) and of host MMP inhibitor (TIMP) activities. The MMP and TIMP families are involved in the regulation of connectivetissue degradation (Herouy, 2001) and the modulation of their activities has been implicated in the virulence of, for example, Pseudomonas aeruginosa and Escherichia coli (de Bentzmann et al., 2000), Borrelia burgdorferi (Gebbia et al., 2001) and Chlamydia pneumoniae (Vehmaan-Kreula et al., 2001). The increase in the degradation of connective tissue produced by an increase in the activities of MMPs and TIMPs is thought to enhance bacterial invasion. However, pathogenic bacteria also secrete their own proteases that are involved in several processes. These include the maturation of other enzymes. For example, Listeria monocytogenes phospholipase C requires a zinc metalloprotease for its activation (Poyart et al., 1993; Raveneau et al., 1992) and intrinsic toxin activity, as does the enterotoxin of Bacteroides fragilis (Kling et al., 1997; Moncrief et al., 1995), the Bacillus anthracis lethal toxin (LeTx) (Hammond \& Hanna, 1998; Hanna, 1999) and the Clostri-

Abbreviations: APR, alkaline protease; APRin, alkaline protease inhibitor; Inh, inhibitor protein. dium spp. neurotoxin (Tonello et al., 1996). Furthermore, bacterial proteases have been implicated in the direct degradation of host connective tissues. This degradative activity is typically associated with the activity of a zinc metalloprotease, such as that seen in Pseudomonas aeruginosa (Olson \& Ohman, 1992) and in Clostridium histolyticum (Yoshihara et al., 1994).

A class of metzincin metalloendopeptidases that have been studied extensively are those that belong to the repeats-in-toxin (RTX) family (Welch, 1991). This family of zinc metalloproteases are secreted to the external medium via a Type I pathway, and members of this family have been identified in Erwinia chrysanthemi (Dahler et al., 1990; Letoffe et al., 1990), Erwinia amylovora (Zhang et al., 1999), Erwinia carotovora (Marits et al., 1999), Pseudomonas aeruginosa (Duong et al., 1992; Guzzo et al., 1990, 1991a, b), Pseudomonas fluorescens (Ahn et al., 1999; Kawai et al., 1999; Liao \& McCallus, 1998), Serratia marcescens (Braunagel \& Benedik, 1990; Letoffe et al., 1991; Nakahama et al., 1986), Pseudomonas brassicacearum (Chabeaud et al., 2001) and Photorhabdus luminescens (M. Valens, A.-C. Broutelle, M. Lefebvre, M. A. Blight, D. Bowen and R. ffrench-Constant, unpublished data). The genetic organization of the operons of members of the RTX family varies between organisms, but essentially includes the structural gene for the RTX zinc metalloprotease(s) and an associated type I secretion apparatus comprising an inner-membrane ATP-binding cassette, a membrane-fusion protein and an outer-membrane pro- 
tein. Moreover, in all cases a gene encoding a specific protease inhibitor is also present. The majority of investigations into these operons have concentrated either on the protease or on its secretion mechanism. Few studies have reported data for the protease inhibitor. The Erwinia chrysanthemi inh gene has been cloned and expressed in Escherichia coli (Letoffe et al., 1989), and the inhibitor protein (Inh) has been shown to be a heat-stable, low-molecular-mass periplasmic enzyme. Furthermore, the inhibitor of Pseudomonas aeruginosa alkaline protease (APR), APRin, has also been characterized with respect to its binding to APR, and it has been shown to require the $\mathrm{N}$-terminal five amino acids for its inhibition activity (Feltzer et al., 2000). In addition, a $12 \mathrm{kDa}$ broad-spectrum protease inhibitor has been described in Photorhabdus luminescens (Wee et al., 2000), which was secreted into the culture medium by phase II phenotypic-variant cells.

Photorhabdus luminescens is a Gram-negative entomopathogenic member of the Enterobacteriaceae (FischerLe Saux et al., 1999). It exists in a symbiotic relationship with entomophagous nematodes of the family Heterorhabditiae [see reviews by Forst et al. (1997) and Forst \& Nealson (1996)]. The bacteria occupy the intestinal tract of the infective stage of the nematode (the infective juvenile). On finding a host, the nematode enters the larva and releases the bacteria into the insect haemocoel (body cavity). The bacteria rapidly divide, producing a wide range of toxins and hydrolytic exoenzymes that are responsible for the death and subsequent bioconversion of the insect larva. These conditions are ideal for nematode growth and development.

Here, we describe the cloning and expression of the Photorhabdus luminescens W14 inh gene in Escherichia coli, together with the purification of Inh from the periplasm of Escherichia coli. We also demonstrate the in vitro inhibition activity of Inh on its purified cognate protease, PrtA.

\section{METHODS}

Bacterial strains and culture conditions. Photorhabdus luminescens wild-type strain W14 was used as the source of inh and of PrtA. The expression and purification of Inh was performed in Escherichia coli DH5 $\alpha$ (F $\phi 80 \mathrm{~d}$ lacZ $\Delta \mathrm{M} 15 \Delta$ (lacZYA$\arg F) U 169$ deoR recA1 endA1 hsdR $17\left(\mathrm{r}_{\mathrm{K}}^{-}, \mathrm{m}_{\mathrm{K}}^{-}\right)$phoA supE44 $\mathrm{l}^{-}$ thi-1 gyrA96 relA1) (Life Technologies). Escherichia coli and Photorhabdus luminescens strains were cultured on LuriaBertani (LB) medium at $30{ }^{\circ} \mathrm{C}$.

Molecular biology techniques. All molecular biology techniques were done as described by Maniatis et al. (1982), unless stated otherwise. Restriction endonuclease (Promega) digestions were performed according to the manufacturer's instructions. Photorhabdus luminescens W14 genomic DNA was isolated as follows. A sample $(1.5 \mathrm{ml})$ of a stationary phase culture of Photorhabdus luminescens W14, grown in LB medium at $30^{\circ} \mathrm{C}$ with agitation, was centrifuged at $8000 \mathrm{~g}$ $\left(4^{\circ} \mathrm{C}\right)$; the cell pellet was resuspended in $567 \mu \mathrm{l}$ TE $(10 \mathrm{mM}$ Tris $/ \mathrm{HCl}, 0 \cdot 1 \mathrm{mM}$ EDTA, $\mathrm{pH} 8 \cdot 0$ ). Following the addition of $30 \mu \mathrm{l}$ of $10 \%(\mathrm{w} / \mathrm{v})$ SDS and $3 \mu \mathrm{l}$ proteinase $\mathrm{K}\left(20 \mathrm{mg} \mathrm{ml}^{-1}\right)$, the cells were incubated at $37^{\circ} \mathrm{C}$ for $1 \mathrm{~h}$. The lysate was mixed thoroughly with $100 \mu \mathrm{l}$ of $5 \mathrm{M} \mathrm{NaCl}$ and $80 \mu \mathrm{l}$ CTAB buffer $[10 \%(\mathrm{w} / \mathrm{v})$ hexadecyltrimethyl ammonium bromide (Sigma) in $0.7 \mathrm{M} \mathrm{NaCl}$ ] and incubated at $65^{\circ} \mathrm{C}$ for $10 \mathrm{~min}$. Upon completion of the incubation, an equal volume of chloroform/ isoamyl alcohol $(24: 1, \mathrm{v} / \mathrm{v})$ was added to the solution and it was mixed thoroughly. The mixture was centrifuged at $8000 \mathrm{~g}$ $\left(4{ }^{\circ} \mathrm{C}\right)$ for $5 \mathrm{~min}$. The aqueous phase was extracted once with phenol/chloroform/isoamyl alcohol $(25: 24: 1, \mathrm{v} / \mathrm{v} / \mathrm{v})$ and centrifuged as before. The aqueous supernatant was then mixed with 0.6 vols of 2-propanol; the precipitated genomic DNA was spooled and washed with $70 \%(\mathrm{v} / \mathrm{v})$ ethanol prior to air-drying and resuspension in $100 \mu \mathrm{l}$ TE buffer.

PCR amplification of inh was achieved by using two oligonucleotide primers (Inh-W14-5', 5' -ATATCATATGGTTTTTGCAGCTTGGTATCTG-3', and Inh-W14-3', 5'-ATATAAGCTTTTATTCATTTTTCTTATTAGTC-3') that provided $5^{\prime}$ and $3^{\prime} \mathrm{NdeI}$ and HindIII restriction sites (shown in bold), respectively, and which amplified the Photorhabdus luminescens W14 inh gene from its initiation to termination codons. Amplification was performed with the following protocol: 5 cycles at $96^{\circ} \mathrm{C}$ for $1 \mathrm{~min}, 40^{\circ} \mathrm{C}$ for $1 \mathrm{~min}$ and $72{ }^{\circ} \mathrm{C}$ for $30 \mathrm{~s}$, followed by 25 cycles at $95^{\circ} \mathrm{C}$ for $1 \mathrm{~min}, 55^{\circ} \mathrm{C}$ for $1 \mathrm{~min}$ and $72^{\circ} \mathrm{C}$ for $30 \mathrm{~s}$. This amplification resulted in a single PCR product of $422 \mathrm{bp}$ in size. Overexpression of Inh was achieved by cloning the PCR product into the plasmid vector pBAD33-GFPuv (Dr H. Benabdelhak, University Paris Sud, France), which consists of pBAD33 containing the gene encoding GFPuv (Clontech) on an NdeI-HindIII restriction fragment. Both the vector pBAD33-GFPuv and the inh PCR product were digested with $\mathrm{NdeI}$ and HindIII. Digested plasmid DNA yielded four fragments of 5338, 540, 125 and $109 \mathrm{bp}$ in size. The $5338 \mathrm{bp} \mathrm{NdeI-HindIII} \mathrm{fragment} \mathrm{was}$ isolated following electrophoresis of the fragments through a $0.7 \%$ agarose/TAE (40 $\mathrm{mM}$ Tris acetate, $2 \mathrm{mM}$ EDTA) gel. It was then ligated with the $407 \mathrm{bp}$ digested PCR product using T4 DNA ligase (Promega). Following their transformation with the ligation product, cells of electrocompetent Escherichia coli $\mathrm{DH} 5 \alpha$ were plated onto LB agar containing $12.5 \mu \mathrm{g}$ chloramphenicol ml ${ }^{-1}$ and incubated at $30^{\circ} \mathrm{C}$. The sequence of the resulting recombinant clone, pINH-1, was confirmed by using an ABI model 373 automated DNA sequencer (Applied Biosystems).

Purification of Inh from the periplasm of Escherichia coli DH5 $\alpha$. A portion of an overnight culture of Escherichia coli $\mathrm{DH} 5 \alpha(\mathrm{pINH}-1)$ that had been grown in LB broth supplemented with $12.5 \mu \mathrm{g}$ chloramphenicol ml $\mathrm{ml}^{-1}$ was inoculated into 11 fresh medium to an $\mathrm{OD}_{450}$ of $0 \cdot 1$. This new culture was incubated at $37^{\circ} \mathrm{C}$ until growth reached an $\mathrm{OD}_{450}$ of 0.6 . Induction of inh expression, from the $\mathrm{pBAD}$ promoter, was achieved by the addition of $\mathrm{L}$-arabinose (to a final concentration of $0 \cdot 1 \%, \mathrm{w} / \mathrm{v}$ ) to the culture and a further $2 \mathrm{~h}$ incubation. After this time, the bacterial cells were pelleted by centrifugation at $6000 \mathrm{~g}\left(4^{\circ} \mathrm{C}\right)$ for $15 \mathrm{~min}$ and the cell pellets were resuspended in $10 \mathrm{ml}$ of $30 \mathrm{mM}$ Tris/ $\mathrm{HCl}$ containing $20 \%(\mathrm{w} / \mathrm{v})$ sucrose $(\mathrm{pH} 8 \cdot 0)$. Following the addition of $20 \mu \mathrm{l}$ of $0 \cdot 5 \mathrm{M}$ EDTA ( $1 \mathrm{mM}$ final concentration) to the suspension, the cells were incubated at room temperature for $10 \mathrm{~min}$, with gentle stirring. The cells were pelleted by centrifugation at $8000 \mathrm{~g}\left(4^{\circ} \mathrm{C}\right)$ for $10 \mathrm{~min}$ and resuspended in $10 \mathrm{ml}$ ice-cold $5 \mathrm{mM} \mathrm{MgSO}$. They were then incubated on ice for $10 \mathrm{~min}$, with gentle stirring. After this time, the cells were centrifuged as above; the supernatant containing the osmotically shocked periplasmic fraction was retained.

Inh was purified from the periplasmic fraction of the super- 

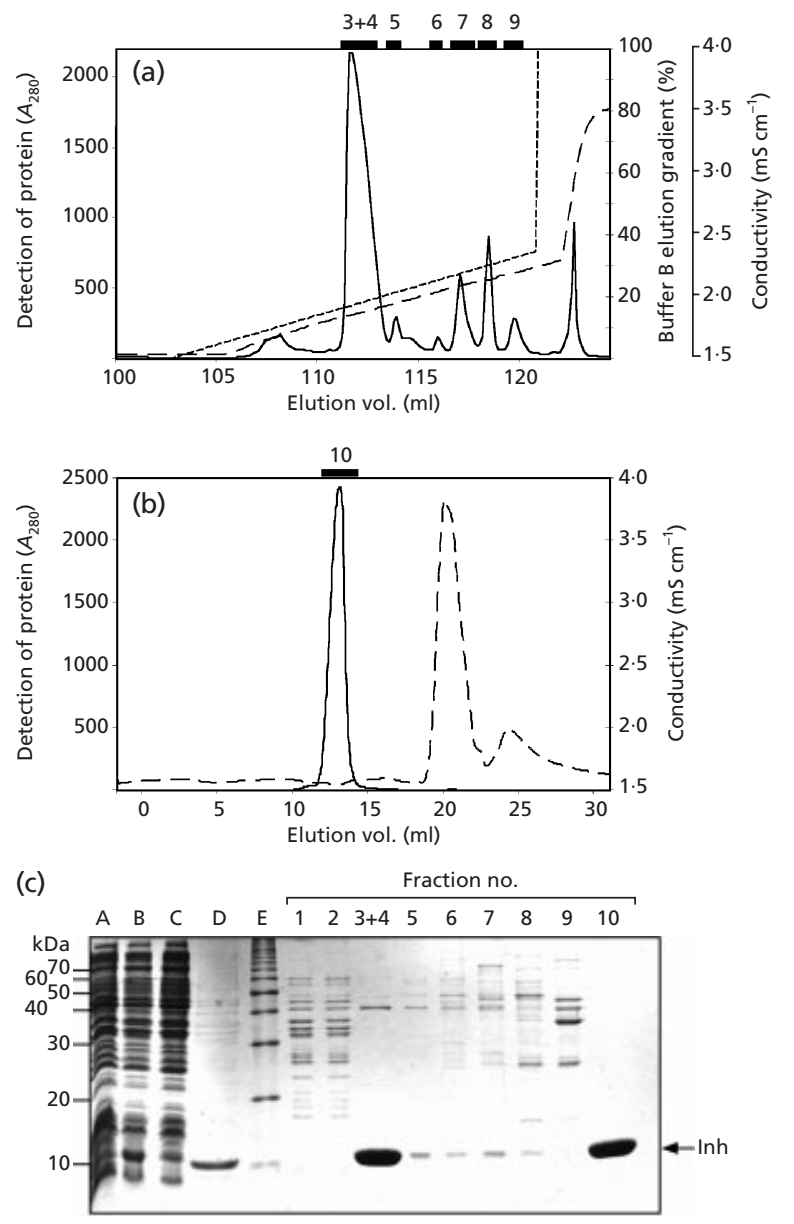

Fig. 1. Purification of overexpressed Inh from the periplasm of Escherichia coli $\mathrm{DH} 5 \alpha(\mathrm{pINH}-1)$. (a) Chromatogram produced following anion-exchange chromatography (MonoQ) of the ammonium-sulphate-precipitated periplasmic fraction. Protein was detected by measuring the absorbance at $280 \mathrm{~nm}$ (solid line). The elution gradient (dashed line) and the conductivity (broken line) are also shown. Collected fractions are indicated by solid boxes above the graph. (b) Chromatogram produced following size-exclusion chromatography (Superdex HR75). The protein and conductivity measurements are as for (a). Fraction 10 (indicated by a solid box above the graph) represents fractions $3+4$ from (a) which had been subjected to further purification by size-exclusion chromatography. Fractions 1 and 2 are not shown on the chromatograms in (a) and (b) because no Inh was detected in them. Units of absorbance in both chromatograms are arbitrary. (c) SDS-polyacrylamide gel $(11 \%$ acrylamide) of proteins from un-induced Escherichia coli $\mathrm{DH} 5 \alpha(\mathrm{pINH}-1)$, induced Escherichia coli $\mathrm{DH} 5 \alpha(\mathrm{pINH}-1)$ and the fractions shown in (a) and (b). Lanes: $A$, un-induced Escherichia coli $\mathrm{DH} 5 \alpha(\mathrm{plNH}-1)$ whole-cell proteins; B, induced Escherichia coli $\mathrm{DH} 5 \alpha(\mathrm{pINH}-1)$ whole-cell proteins (induced with $0.1 \%$, w/v, arabinose; $2 \mathrm{~h}$ incubation); $\mathrm{C}$, cell pellet following periplasmic extraction; $D$, periplasmic fraction; $E$, molecular mass markers. Lanes 1-10 refer to the fractions indicated on the chromatograms in (a) and (b).

natant by anion-exchange and size-exclusion chromatography using an AKTA FPLC system (Amersham-Pharmacia Biotech) at $10{ }^{\circ} \mathrm{C}$ as follows. A MonoQ HR 5/5 anion-exchange column (Amersham-Pharmacia Biotech) that had been equilibrated in Buffer A (20 mM Tris/ $\mathrm{HCl}, \mathrm{pH} 7 \cdot 5)$ was loaded with the periplasmic fraction (approx. $40-70 \mu \mathrm{g}$ total protein $\mathrm{ml}^{-1}$ )

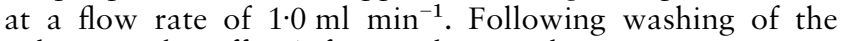
column with Buffer A for 2 column volumes, proteins were eluted with a linear gradient of Buffer B $(0-35 \%$; Buffer $\mathrm{A}+1 \mathrm{M} \mathrm{NaCl}$ ) over 20 column volumes at a flow rate of $1.0 \mathrm{ml} \mathrm{min}^{-1}$. Inh eluted at approximately $250 \mathrm{mM} \mathrm{NaCl}$ and was further purified by size-exclusion chromatography on a Superdex HR75 column (Amersham-Pharmacia Biotech) using Buffer A as the mobile phase. Eluted Inh was supplemented with $10 \%(\mathrm{v} / \mathrm{v})$ glycerol and stored at $-20{ }^{\circ} \mathrm{C}$ prior to further analysis.

Purification of PrtA. Photorhabdus luminescens W14 phase I cells were grown in $1 \mathrm{l}$ of LB medium at $30^{\circ} \mathrm{C}$ (agitation at 250 r.p.m.) to the late stationary phase of growth over 48 h. The culture supernatant was retained following centrifugation of the culture at $8000 \mathrm{~g}\left(4^{\circ} \mathrm{C}\right)$ for $30 \mathrm{~min}$. Solid ammonium sulphate was added to the supernatant to a final saturation of $80 \%$, and proteins were precipitated at $4{ }^{\circ} \mathrm{C}$ for $2 \mathrm{~h}$ with gentle stirring. Precipitated material was collected by centrifugation at $10000 \mathrm{~g}\left(4^{\circ} \mathrm{C}\right)$ for $30 \mathrm{~min}$, and the pellets were combined and solubilized in a total volume of $80 \mathrm{ml}$ of a solution containing $1 \mathrm{M}$ ammonium sulphate and $50 \mathrm{mM}$ sodium phosphate $(\mathrm{pH} 8 \cdot 0)$. Chromatographic procedures were performed on an AKTA FPLC system at $20^{\circ} \mathrm{C}$. Following a final clarification of the solubilized supernatant by centrifugation at $10000 \mathrm{~g}\left(4^{\circ} \mathrm{C}\right)$ for $30 \mathrm{~min}$, the solubilized proteins were loaded onto $30 \mathrm{ml}$ of Octyl Sepharose 4 Fast Flow hydrophobic interaction resin packed in an XK16/20 column (Amersham-Pharmacia Biotech) at a flow rate of $1 \mathrm{ml} \mathrm{min}{ }^{-1}$. Elution of the proteins was performed with a linear gradient over 20 column volumes into $5 \mathrm{mM}$ sodium phosphate (pH 8.0); fractions of $5 \mathrm{ml}$ were collected. The protease activity of the fractions was determined by spectrophotometric determination of the Coomassie blue released at $595 \mathrm{~nm}$ from Blue Hide Azure powder (Sigma) as follows. Blue Hide Azure Powder was resuspended to $30 \mathrm{mg} \mathrm{ml}^{-1}$ in a solution containing $20 \mathrm{mM}$ Tris $/ \mathrm{HCl}$ and $5 \mathrm{mM} \mathrm{CaCl}_{2}$ (pH 8.0). Aliquots $(5 \mu \mathrm{l})$ of each fraction were assayed for $30 \mathrm{~min}$ at $37^{\circ} \mathrm{C}$ with $0.5 \mathrm{ml}$ of the Blue Hide Azure suspension in $1.5 \mathrm{ml}$ Eppendorf tubes, with constant agitation. Following incubation, the assays were centrifuged and the absorption value at $595 \mathrm{~nm}$ was determined for the supernatants. One unit of protease activity was defined as $0 \cdot 01 A_{595}$ units released $\min ^{-1}(\mathrm{ml}$ fraction assayed $)^{-1}$. Fractions containing protease activity were pooled and applied directly to a MonoQ HR5/5 column (Amersham-Pharmacia Biotech) that had been equilibrated with $5 \mathrm{mM}$ sodium phosphate $(\mathrm{pH} 8 \cdot 0)$. Fractions of $0.5 \mathrm{ml}$ were collected during elution with a solution containing $5 \mathrm{mM}$ sodium phosphate and $1 \mathrm{M} \mathrm{NaCl}$ ( $\mathrm{pH} \mathrm{8.0)} \mathrm{over} 10$ column volumes. Protease-containing fractions were assayed as described above and eluted at approximately $300 \mathrm{mM} \mathrm{NaCl}$. These were then analysed by SDS-PAGE.

Interactions between the protease (PrtA) and the inhibitor (Inh). The demonstration of stoichiometric interactions between PrtA and its cognate inhibitor (Inh) was done by anionexchange chromatography. Purified PrtA and Inh (both at a concentration of $1 \mathrm{mg} \mathrm{ml}^{-1}$ ) were diluted in $1 \mathrm{ml}$ of Buffer IEX-A (20 mM Tris/HCl, $1 \mathrm{mM} \mathrm{CaCl}, \mathrm{pH} \mathrm{8.0)}$, either individually or together to a final concentration of $93 \mu \mathrm{M}-$ this required $50 \mu \mathrm{g}$ of PrtA and $11 \mu \mathrm{g}$ of Inh. Samples were analysed by anion-exchange chromatography on a MonoQ HR 10/10 anion-exchange column (Amersham-Pharmacia Biotech) using an ÄKTA FPLC system. Samples were loaded in Buffer IEX-A and eluted with a linear gradient of Buffer IEX-B (Buffer IEX-A + $1 \mathrm{M} \mathrm{NaCl}$ ) over 10 column volumes to a final concentration of $0.5 \mathrm{M} \mathrm{NaCl}$. 
Protein analysis. Protein concentrations were measured using the Coomassie Plus Protein Assay Reagent (Pierce) and denaturing SDS-PAGE (15\%, w/v, acrylamide), performed as described by Laemmli (1970). Proteins were stained with Coomassie Brilliant Blue R250 (Sigma).

Protease inhibition assay. Purified Photorhabdus luminescens W14 PrtA was prepared as described above. The protease activity of PrtA was measured as the increase of BODIPY-FL fluorescence released from cleaved BODIPY-FL-labelled casein using the EnzChek Protease Assay Kit (Molecular Probes). Measurements of fluorescence were made in a Biolumin Microplate Fluorescence Spectrophotometer (Molecular Dynamics), with excitation and emission wavelengths of 485 and $530 \mathrm{~nm}$, respectively. Purified PrtA dissolved in $20 \mathrm{mM}$ Tris/ $\mathrm{HCl}$ containing $5 \mathrm{mM} \mathrm{CaCl}_{2}$ (pH 8.0) was assayed in a total volume of $200 \mu \mathrm{l}$, with BODIPY-FL casein added to a final concentration of $5 \mu \mathrm{g} \mathrm{ml}^{-1}$. Alternatively, assays were conducted as described above but in a final volume of $1 \mathrm{ml}$ and using an SFM25 spectrofluorometer (Biotek Kontron) with the same excitation and emission wavelengths. All kinetic experiments were repeated in triplicate and Figs 1 and 4-6 represent the mean data with a typical SE of between 2 and $5 \%$.

\section{RESULTS}

\section{Cloning, expression and purification of Photorhabdus luminescens Inh}

The Photorhabdus luminescens W14 zinc metalloprotease inhibitor gene, inh, was obtained as a 422 bp PCR product (see Methods for details). Following digestion of the $422 \mathrm{bp}$ fragment with $\mathrm{NdeI}$ and HindIII, the resulting $407 \mathrm{bp}$ cohesive fragment was ligated to the $5338 \mathrm{bp}$ fragment from pBAD33-GFPuv. This ligation resulted in pINH-1, which expressed inh from the arabinose-inducible pBAD promoter.

Inh production by Escherichia coli $\mathrm{DH} 5 \alpha(\mathrm{pINH}-1)$ was induced by incubating a culture of the cells for $2 \mathrm{~h}$ in the presence of $0 \cdot 1 \%(\mathrm{w} / \mathrm{v})$ L-arabinose. After this incubation, Inh was purified from the isolated periplasmic fraction of Escherichia coli DH $5 \alpha(\mathrm{pINH}-1)$ in two chromatographic steps. Fig. 1 illustrates the chromatograms produced following anion-exchange (Fig. 1a) and size-exclusion (Fig. 1b) chromatography, together with SDS-PAGE analysis of the fractions produced by these two methods (Fig. 1c).

Following the induction of its expression, Inh could be seen as a low-molecular-mass species $(11 \mathrm{kDa})$ that accumulated in whole cells of Escherichia coli DH5 $\alpha$ (pINH-1) (Fig. 1c, lane B). Fractionation of the cells into a periplasmic fraction (Fig. 1c, lane D) and a residual whole-cell fraction (Fig. 1c, lane C) demonstrated that the majority of Inh was localized in the periplasmic fraction, as expected. This resulted in a high enrichment of Inh, with Inh representing approximately $65 \%$ of the total periplasmic protein as estimated from the peak area in the anion-exchange chromatogram (Fig. 1a). SDS-PAGE analysis of the chromatographic fractions clearly showed that all of the Inh bound to the MonoQ resin (absence of Inh in flow-through fractions 1 and 2, Fig. 1c) and that it eluted in a compact peak, with minor contaminating proteins appearing at approximately 42 and $47 \mathrm{kDa}$ (Fig. 1c, lane $3+4$ ). The material from fractions $3+4$ was further purified by size-exclusion chromatography on a Superdex HR75 column (Fig. 1b), resulting in a single migrating $11 \mathrm{kDa}$ form of Inh that was estimated to be $99 \%$ pure (Fig. 1c, lane 10).

Inhibition of metzincin metalloendopeptidases by the Inh family minimally requires the $\mathrm{N}$-terminal five amino acid residues of the Inh proteins (Feltzer et al., 2000). Consequently, it was important to determine whether the $\mathrm{N}$ terminus of the recombinant Inh purified from the periplasm of Escherichia coli DH5 $\alpha$ (pINH-1) was identical to that of wild-type Inh from Photorhabdus luminescens W14. Hence, we determined the N-terminalamino-acid sequence of the wild-type Inh purified from Photorhabdus luminescens W14 and of the recombinant Inh purified from Escherichia coli DH5 $\alpha(\mathrm{pINH}-1)$. For both the wild-type and the recombinant protein the $\mathrm{N}$ terminal sequence was SSLVL, indicating that leader peptidase processing was identical in both organisms. Furthermore, matrix-assisted laser desorption ionization/time of flight (MALDI/TOF) mass spectrometry indicated a molecular mass of $11951 \mathrm{Da}$ for Inh, in excellent agreement with the predicted mass of 11953 Da for mature Inh. Therefore, recombinant Inh, which could be purified in substantial amounts from Escherichia coli DH5 $\alpha$ (pINH-1), was used for PrtA inhibition studies.

\section{Comparison of Photorhabdus luminescens W14 Inh with other zinc metalloprotease inhibitors}

A multiple-amino-acid-sequence alignment of the 13 available Inh proteins (Fig. 2) showed that there are two highly conserved domains between residues 25 and 41 and residues 67 and 100 (Photorhabdus luminescens W14 Inh co-ordinates) of the Inh proteins. Domain 1 encompasses the predicted leader peptidase cleavage site with the consensus sequence MA/SSL, resulting in the mature polypeptide possessing a strictly conserved Ser at position 2. The crystal structure of the complex between the $S$. marcescens metalloprotease PrtSM and the Erwinia chrysanthemi inhibitor (Baumann et al., 1995) (Protein database accession no. 1SMP; http://www. rcsb.org/pdb/) and of the complex between Pseudomonas aeruginosa APR and APRin (Hege et al., 2001) indicates that both Inh and APRin have a compact globular structure with an unstructured $\mathrm{N}$ terminus in direct interaction with the zinc-binding pocket of the protease active site. The first amino acid of Inh is not strictly conserved as it is the main chain atoms that form the inhibitory hydrogen bonds, although $\mathrm{Ser}_{1}$ of the Pseudomonas aeruginosa APRin forms a co-ordinate bond with the zinc ion (Hege et al., 2001). The strictly conserved $\mathrm{Ser}_{2}$ residue bonds the catalytic Glu of the protease and $\mathrm{Leu}_{3}$ is accommodated in a hydrophobic pocket. The second highly conserved domain within the Inh family - Domain 2 - is characterized by a $\beta$-sheet being bent into a loop by the strictly conserved Pro $_{62}$ 

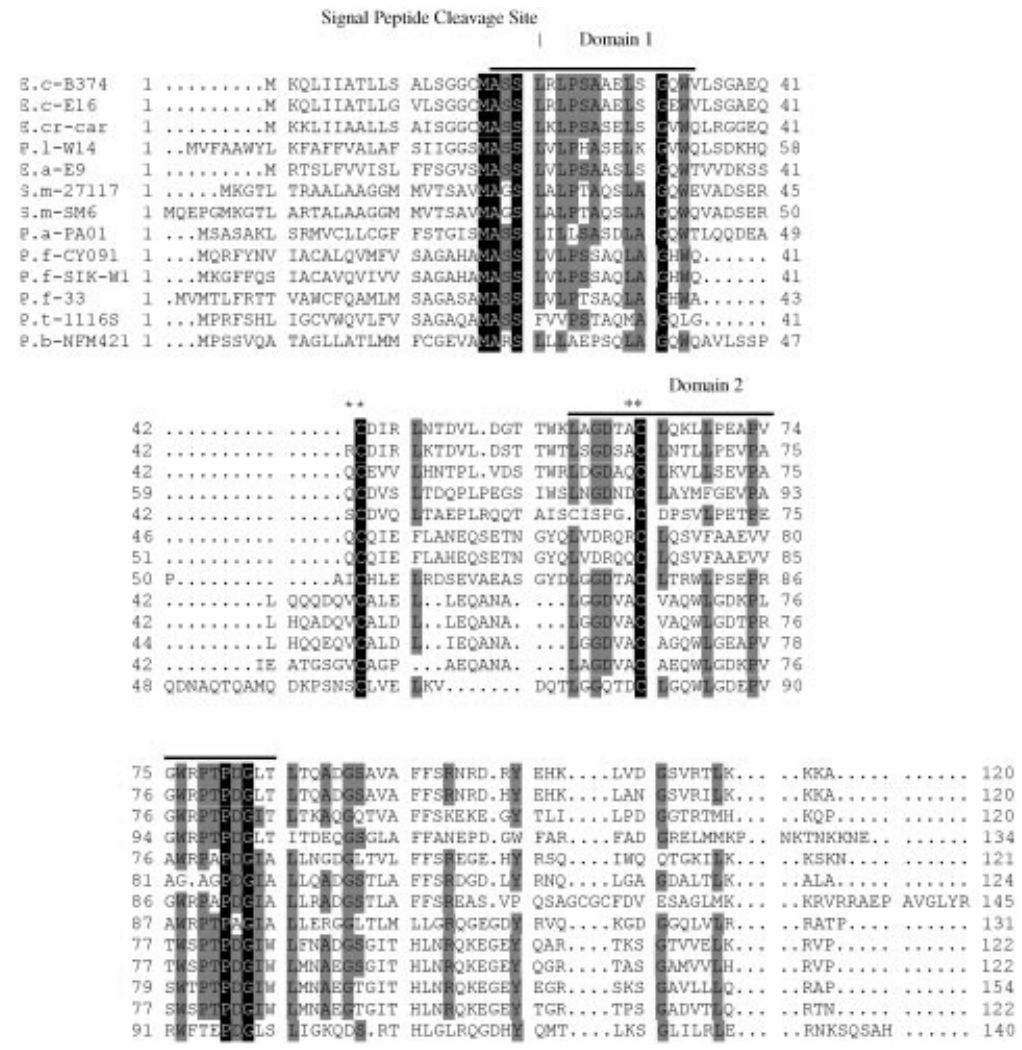

Fig. 2. Multiple-sequence alignment of 13 members of the Inh family. The signal peptide cleavage site is indicated by a vertical bar (MA/SSL), the conserved Domains, 1 and 2, are indicated by solid horizontal bars and the conserved Cys residues involved in a disulphide bond are marked by a double asterisk. E.c-B374, Erwinia chrysanthemi B374; E.c-E16, Erwinia chrysanthemi E16; E.cr-car, Erwinia carotovora sub. carotovora; P.I-W14, Photorhabdus luminescens W14; E.a-E9, Erwinia amylovora E9; S.m-27117, S. marcescens ATCC 27117; S.m-SM6, S. marcescens SM6; P.a-PA01, Pseudomonas aeruginosa PA01; P.f-CY091, Pseudomonas fluorescens CY091; P.f-SIK-W1, Pseudomonas fluorescens SIK-W1; P.f-33, Pseudomonas fluorescens 33; P.t-1116S, Pseudomonas tolaasii 1116S; P.b-NFM421, Pseudomonas brassicacearum NFM421.

\author{
E. chrysanthemi-B374 \\ E. chrysanthemi-E16 \\ E. carotovora-sub-carotovora \\ P. Iuminescens-W14 \\ E. amylovora-E9 \\ S.marcescens-ATCC27117 \\ S. marcescens-SM6 \\ $P$. aeruginosa-PA01 \\ P. fluorescens-CYO91 \\ $P$. fluorescens-SIK-W1 \\ P. fluorescens-33 \\ P.tolaasii-1116S \\ P.brassicacearum-NEM4 21
}

$\begin{array}{llllllllllllllll}---- & 89.2 & 70.0 & 49.3 & 50.8 & 44.0 & 37.2 & 45.8 & 43.0 & 41.4 & 40.8 & 39.1 & 31.9\end{array}$

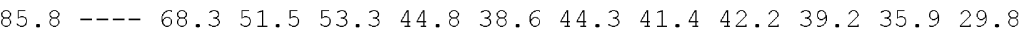
$\begin{array}{llllllllllllll}59.2 & 57.5 & --- & 52.2 & 47.5 & 41.6 & 37.2 & 44.3 & 35.9 & 36.7 & 33.8 & 33.6 & 28.4\end{array}$ $40.341 .0 \quad 45.5 \quad---4 \begin{array}{lllllllllllll}41.0 & 38.1 & 34.7 & 43.8 & 35.6 & 37.0 & 34.6 & 33.3 & 27.9\end{array}$ $\begin{array}{llllllllllllllll}37.7 & 38.5 & 35.2 & 30.6 & --- & 43.7 & 39.3 & 45.0 & 32.6 & 33.3 & 31.3 & 33.3 & 26.2\end{array}$ $33.6 \quad 30.4 \quad 27.2 \quad 25.4 \quad 31.7 \quad----69.7 \quad 39.7 \quad 34.4 \quad 34.4 \quad 32.3 \quad 28.924 .1$

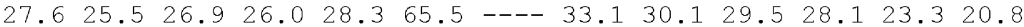
$\begin{array}{llllllllllllll}30.5 & 28.2 & 30.5 & 28.5 & 32.1 & 34.4 & 26.4 & --- & 38.2 & 42.0 & 38.3 & 38.2 & 32.6\end{array}$

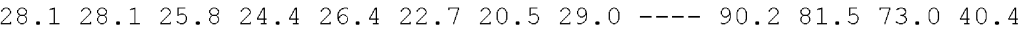
$\begin{array}{llllllllllllllll}25.8 & 26.6 & 26.6 & 23.7 & 25.6 & 20.3 & 18.5 & 30.5 & 82.8 & ---- & 83.9 & 70.5 & 39.7\end{array}$

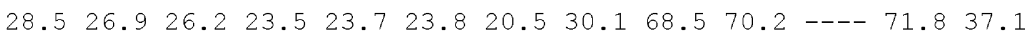
$\begin{array}{llllllllllllllll}25.8 & 22.7 & 24.2 & 20.7 & 21.7 & 18.0 & 14.4 & 28.2 & 62.3 & 63.1 & 58.9 & --- & -35.5\end{array}$ $23.422 .0 \quad 19.1 \quad 19.0 \quad 19.1 \quad 21.3 \quad 17.5 \quad 26.2 \quad 31.930 .5 \quad 29.4 \quad 26.2$----

Fig. 3. Similarity matrix for proteins belonging to the Inh family.

(mature protein co-ordinates). This loop is in close proximity to the extended $\mathrm{N}$ terminus, with a closest distance of $3.52 \AA$ between the $\operatorname{Pro}_{62}$ and $\mathrm{Arg}_{4}$ side chains. Domain 2 may stabilize the N-terminal of Domain 1 via the $\operatorname{Pro}_{62}$ loop, enabling efficient interaction and insertion of the Inh $\mathrm{N}$ terminus into the protease active site. Other than Domains 1 and 2, the intervening sequences of Inh are poorly conserved and result in percentage identity and similarity values that vary from 89.2 and $85.8 \%$ identity and similarity, respectively, between Erwinia chrysanthemi B374 and Erwinia chrysanthemi E16 to only $20 \cdot 8 \%$ identity between Pseudomonas brassicacearum NFM421 and S. marcescens SM6 and 18.0 \% similarity between Pseudo- monas tolaasii 1116S and S. marcescens ATCC 27117 (Fig. 3).

\section{Interaction of PrtA with Inh}

The complexes formed between the S. marcescens PrtSM and the Erwinia chrysanthemi inhibitor (Baumann et al., 1995) and between APR and APRin (Feltzer et al., 2000) both indicate a 1:1 molar stoichiometry for inhibition. To demonstrate an interaction between the purified Photorhabdus luminescens W14 proteins, PrtA and Inh were analysed by anion-exchange chromatography (see Methods) either individually or following mixing (see Methods) and incubation at $4{ }^{\circ} \mathrm{C}$ for $15 \mathrm{~min}$. 


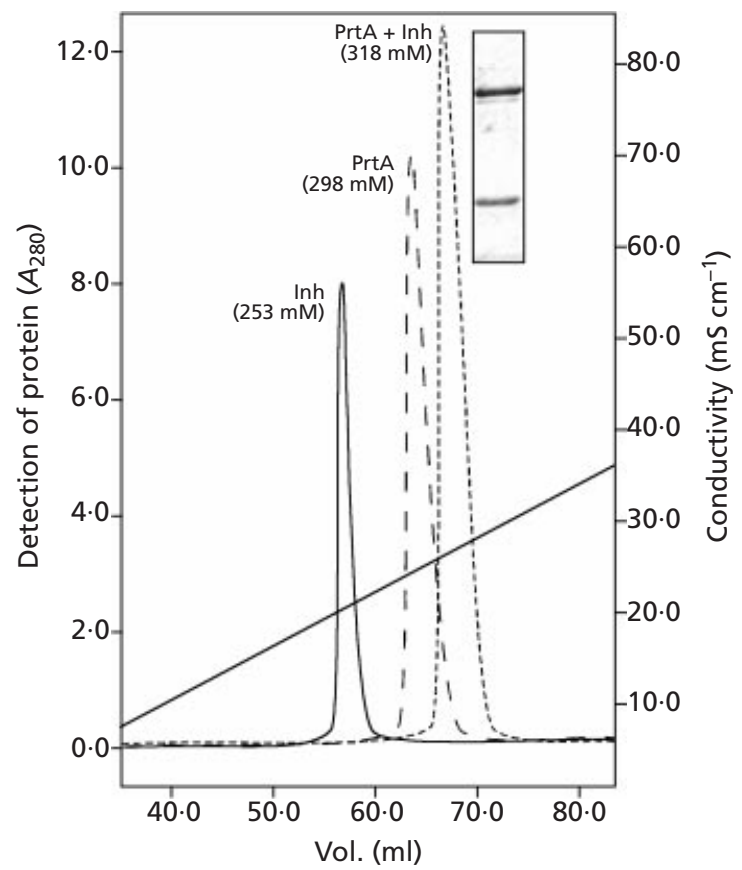

Fig. 4. Anion-exchange chromatography of Prt-Inh complexes. Equimolar $(93 \mu \mathrm{M})$ amounts of Inh $(11 \mu \mathrm{g})$ and PrtA $(50 \mu \mathrm{g})$ were either analysed individually or following mixing and incubation on ice for $15 \mathrm{~min}$ upon a MonoQ HR10/10 anionexchange column at a flow rate of $1 \mathrm{ml} \mathrm{min}^{-1}$ and linear elution with $\mathrm{NaCl}$. Peaks are as labelled. Units of absorbance are arbitrary.

The theoretical charges of PrtA, Inh and PrtA + Inh at $\mathrm{pH} 8.0$ were obtained from the titration curves calculated at http://www.up.univ-mrs.fr/ wabim/ d_abim/compo-p.html and were $-4.88,-30.69$ and $-37 \cdot 39$, respectively. Therefore, one would expect that the PrtA-Inh complex would be retained more strongly upon an anion-exchange resin than either Inh or PrtA alone. Fig. 4 illustrates the chromatograms obtained following analysis of PrtA, Inh and PrtA + Inh on a MonoQ HR 10/10 column. Equimolar loadings $(93 \mu \mathrm{M})$ of each protein were analysed and the curve for PrtA + Inh showed no residual PrtA or Inh peaks, indicating that all of the PrtA and Inh were combined as a bimolecular species, eluting at $318 \mathrm{mM} \mathrm{NaCl}$ rather than at $253 \mathrm{mM}$ (Inh alone) and $298 \mathrm{mM} \mathrm{NaCl}$ (PrtA alone). Similar experiments (data not shown) using 2:1 PrtA/Inh or Inh/PrtA showed residual peaks for PrtA and Inh, respectively. Therefore, these data demonstrate a 1:1 molecular stoichiometry between PrtA and Inh when they are in solution together.

\section{Inhibition of PrtA by Inh}

Casein hydrolysis by purified Photorhabdus luminescens W14 PrtA in the presence of increasing concentrations of Inh was measured. PrtA was diluted to a concentration of $1 \mathrm{nM}$ (see Methods) and Inh was added to give molar ratios of PrtA/Inh ranging from 1:0 to 1:10. Proteins were incubated for $2 \mathrm{~min}$ at $25^{\circ} \mathrm{C}$ followed by the addition of the PrtA substrate, BODIPY-FL-labelled casein. The increase in fluorescence was measured (Fig. 5a) and the slope of steady-state hydrolysis was calculated between 120 and $540 \mathrm{~s}$. A bar graph of the substrate-hydrolysis rate for each PrtA/Inh molar ratio (Fig. 5b) clearly demonstrated that little significant inhibition of Prt A by Inh occurred until a molar ratio of 1:0.5 PrtA/Inh was used; total inhibition was observed at molar ratios of $1: 1 \mathrm{PrtA} / \mathrm{Inh}$ and above. These data are consistent with the unimolecular stoichiometry of inhibition described above and are indicative of a strong interaction between the two proteins that results in the efficient inhibition of PrtA by Inh. To further characterize the interaction between PrtA and Inh, the association constant for the PrtA-Inh complex was determined.

\section{Kinetics of PrtA inhibition by Inh}

Many protease $(\mathrm{P})$-inhibitor $(\mathrm{I})$ interactions are characterized by classical 'slow-binding' kinetics with a typical equilibrium characterized by:

$$
\mathrm{P}+\mathrm{I} \underset{k_{-1}}{\stackrel{k_{1}}{\leftrightharpoons}} \mathrm{PI} \stackrel{k_{2}}{\rightarrow} \mathrm{P}-\mathrm{I}
$$

Not all protease-inhibitor interactions result in covalent bonding (i.e. an irreversible reaction), and frequently inhibitor binding is so tight that one can not determine a binding constant. Under these conditions the reaction is classified as 'pseudo-irreversible' and the most relevant quantity to measure is the apparent rate of inhibition (or association), $k_{\text {ass }}$, where:

$k_{\mathrm{ass}}=\frac{k_{1} k_{2}}{k_{-1}}$

The inhibition curves for purified Photorhabdus luminescens W14 PrtA were determined using BODIPY-FLlabelled casein with $1.0 \mathrm{nM}$ PrtA and either a $1: 1$ or 1:10 PrtA/Inh molar ratio (Fig. 6). Following the addition of Inh to the PrtA/casein-hydrolysis reaction, a rapid decline in PrtA activity was observed as detected by the reduced rate of change of fluorescence due to liberated BODIPY-FL-labelled peptides. At a molar ratio of 1:10 PrtA/Inh (and higher ratios; data not shown) inhibition was sufficiently rapid that a pseudofirst-order kinetic analysis was not possible. Therefore, to determine a reasonable estimate of $k_{\text {ass }}$, a secondorder analysis was performed at a molar ratio of $1: 1$ analysing the data from the addition of Inh $(t=120 \mathrm{~s})$ to stable inhibition at $t=240 \mathrm{~s}$. A plot of the reciprocal residual enzyme concentration against time (Fig. 6, inset) yielded a straight line with slope $k_{\text {ass }}=1.34 \times$ $10^{7} \mathrm{M} \mathrm{s}^{-1}$ and an intercept $\left(9 \cdot 98 \times 10^{8} \mathrm{M}^{-1}\right)$ equal to the reciprocal of the starting enzyme concentration. The latter is in good agreement with the initial enzyme concentration of $1.0 \mathrm{nM}$. The large value for $k_{\text {ass }}$ indicates that the PrtA-Inh complex is highly stable and that if an intermediate complex exists it is rapidly 

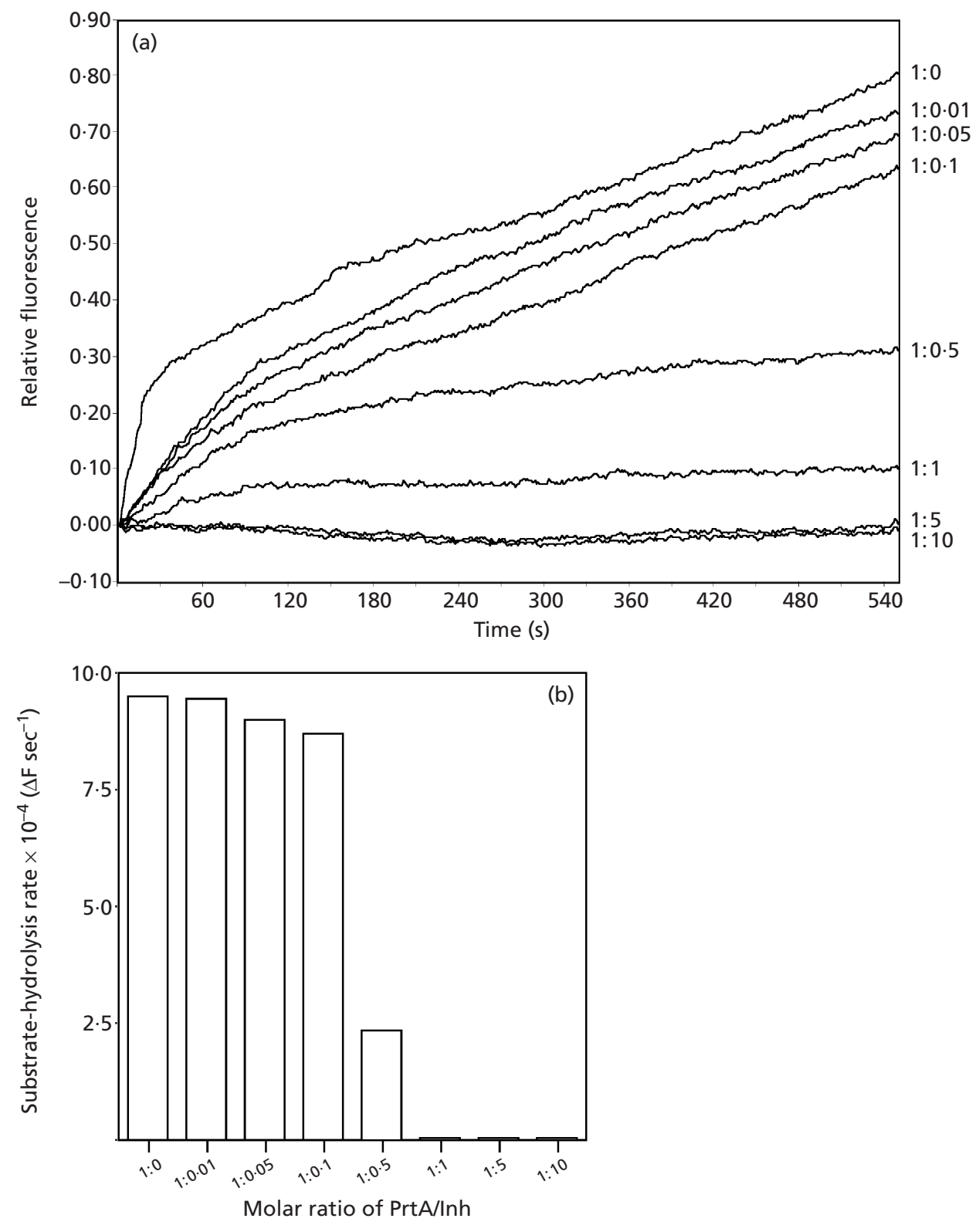

Fig. 5. Inhibiton of PrtA activity by Inh. (a) PrtA (1 nM) was pre-incubated with Inh in molar ratios ranging from $1: 0$ to 1:10 PrtA/Inh at $25^{\circ} \mathrm{C}$ for $2 \mathrm{~min}$. BODIPY-FL-labelled casein substrate $\left(5 \mu \mathrm{g} \mathrm{ml}^{-1}\right)$ was added to the mixture and the fluorescence generated by the release of labelled peptides was followed with time. (b) Bar graph of the ratios shown in (a) against the steady-state substrate-hydrolysis rate measured as the slope of traces in (a) between 120 and $540 \mathrm{~s}$.

converted to the stable inhibited form. Since PrtA-Inh can be dissociated by the addition of SDS, no covalent modification of the complex occurs; therefore, we can consider the PrtA-Inh interaction to be pseudo-irreversible. Thus, it is possible to calculate the half-life of protease inhibition from:

$t_{\frac{1}{2}}=\frac{0.693}{k_{\mathrm{ass}} \times[\mathrm{I}]}$

For the Photorhabdus luminescens W14 PrtA-Inh complex, the protease inhibition $t_{1 / 2}=51.7 \mathrm{~s}$. Studies of PrtA homologues and their kinetic interactions with their cognate Inh homologues will yield comparative inhibition data for that presented above.

\section{DISCUSSION}

Proteases and protease inhibitors are important for many biological processes and have been exploited in industrial applications, such as biological detergent production, and in clinical treatments, including HIV therapy (Brechtl et al., 2001). Specific protease inhibitors have been suggested as new treatments in bacterial 


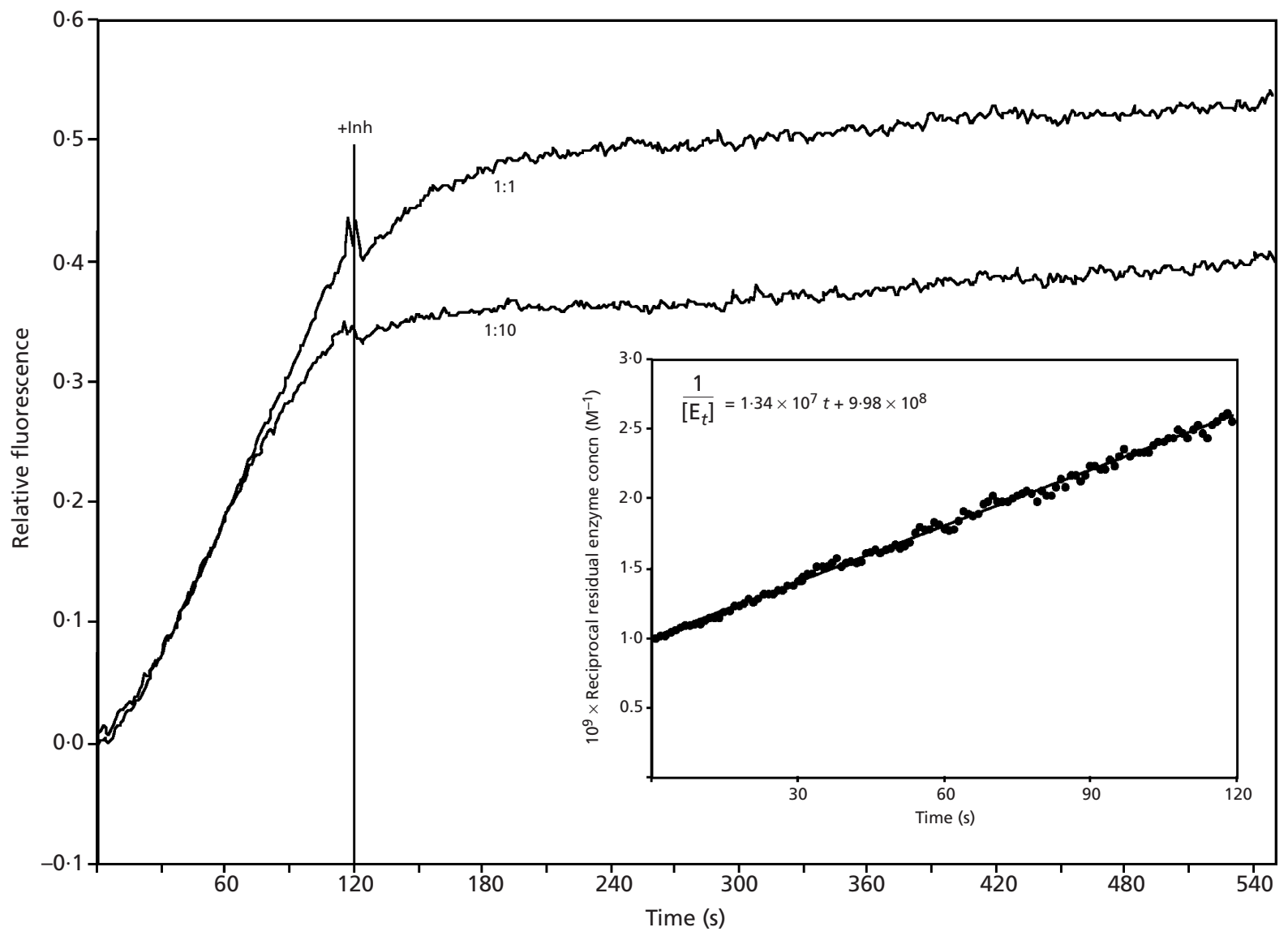

Fig. 6. Kinetics of PrtA inhibition by Inh. PrtA $(1 \mathrm{nM})$ was incubated with BODIPY-FL-labelled casein $\left(5 \mu \mathrm{g} \mathrm{ml} \mathrm{I}^{-1}\right)$; Inh was added at either a 1:1 or a 1:10 PrtA/Inh molar ratio after $120 \mathrm{~s}$. Fluorescence was monitored over time. The inset graph represents a plot of the reciprocal residual enzyme concentration $\left(1 /\left[\mathrm{E}_{t}\right]\right)$ against time at a PrtA/Inh molar ratio of $1: 1$ (second-order kinetics), which yields a straight line with slope $k_{\text {ass }}=1.34 \times 10^{7} \mathrm{M} \mathrm{s}^{-1}$ and an intercept $\left(9.98 \times 10^{8} \mathrm{M}^{-1}\right)$ equal to the reciprocal of the starting enzyme concentration.

infections where the proteases are second-generation antibiotic targets (Travis \& Potempa, 2000). Photorhabdus luminescens is a natural pathogen for insect larvae, but it has recently been identified in human infections (Peel et al., 1999). During insect infection, Photorhabdus luminescens secretes a wide variety of hydrolytic enzymes to the external medium, including lipase (Wang \& Dowds, 1993), chitinase (Chen et al., 1996) and protease (Ong \& Chang, 1997). The role of these enzymes is thought to be for the bioconversion of the insect cadaver to provide nutrients for the development of the Heterorhabditis nematodes that, in symbiosis with Photorhabdus luminescens bacteria, are responsible for the penetration and infection of the insect larva. Many pathogenic bacteria use hydrolytic enzymes to penetrate host tissues during invasion, e.g. hyaluronidase is secreted by group A streptococci (Hynes et al., 2000). It is therefore not inconceivable that the extracellular hydrolytic enzymes of Photorhabdus luminescens would provide it with an advantage in human infections for tissue penetration, if this normally psychrophilic bacterium were adapted to growth at a higher temperature. Other bacteria not normally associ- ated with human infections have also been found to be clinically relevant. For example, Pseudomonas fluorescens is a psychrophilic bacterium that is typically associated with food contamination, yet it has been found in nosocomial infections of humans. The origin of these infections is thought to be either directly via deep wounding (Dubey et al., 1988) or via bacterial colonization of medical equipment (Burgos et al., 1996; Hsueh et al., 1998). Therefore, it is important to consider pathogenic bacteria not normally associated with human infection to be potential human pathogens. An understanding of the biology of such organisms may identify potential second-generation antibiotic targets and extracellular-enzyme inhibitors.

The zinc metalloprotease inhibitor of Photorhabdus luminescens presented in this work has a high specificity and affinity for the extracellular PrtA protease. Analysis of the complexes formed between the $S$. marcescens metalloprotease (PrtSM) and the Erwinia chrysanthemi inhibitor (Baumann et al., 1995) and between Pseudomonas aeruginosa APR and APRin (Hege et al., 2001) indicate that the mechanism of inhibition of this class of 
proteases is unique and involves the extreme $\mathrm{N}$ terminus of the inhibitor molecule. The N-terminal five amino acid residues of the inhibitor protein are an absolute requirement for inhibition, as demonstrated by deletion studies on APRin (Feltzer et al., 2000) and on $S$. marcescens SMPI (Bae et al., 1998), where serial deletion of residues $1-5$ of APRin resulted in a progressive reduction of its affinity for APR and deletion of the Nterminal three residues of SMPI resulted in reduced protease inhibition, respectively. However, studies have demonstrated that there are several important differences in the apparent role of the extreme $\mathrm{N}$ terminus of inhibition proteins of different bacterial species, and these suggest possible subtle differences in the mechanism of action for the different protein inhibitors. The deletion of $\mathrm{Gly}_{1}$ and $\mathrm{Ser}_{2}$ from $S$. marcescens SMPI had little effect upon SMP inhibition, whereas the deletion of $\mathrm{Leu}_{3}$ resulted in severely impaired function (Bae et al.,

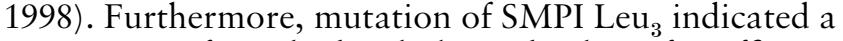
requirement for a hydrophobic side chain for efficient inhibition (Bae et al., 1998). Conversely, for both Pseudomonas aeruginosa APRin and Erwinia chrysanthemi Inh, the extreme $\mathrm{N}$-terminal residues appear to be absolutely necessary for inhibition (Feltzer et al., 2000; Letoffe et al., 1989). Circular dichroism studies of APRin also indicate that there may be structural differences between different inhibitor molecules, when compared with Erwinia chrysanthemi Inh (Feltzer et al., 2000). These data may, in part, contribute to the observations of highly varied affinities between inhibitors and their cognate metzincin proteases. APRin binds to APR with a $K_{\mathrm{D}}$ of approximately $4 \mathrm{pM}$ (Feltzer et al., 2000), whereas $K_{\mathrm{D}}$ values for $S$. marcescens SMPI and SMP (Bae et al., 1998) and for Erwinia chrysanthemi PrtA, PrtB and PrtC and their cognate Inh (Letoffe et al., 1989) are reported as $0.7 \mu \mathrm{M}$ and $1-10 \mu \mathrm{M}$, respectively. The data presented here for the inhibition of PrtA by Photorhabdus luminescens Inh also indicate a strong and highly stable interaction $\left(k_{\mathrm{ass}}=1.34 \times 10^{7} \mathrm{M} \mathrm{s}^{-1}\right)$; they also indicate that if an intermediate complex exists it is rapidly converted to the stable inhibited form. We were unable to estimate a $K_{\mathrm{D}}$ value for the association of Photorhabdus luminescens PrtA and Inh as (unlike for the Pseudomonas aeruginosa and Erwinia chrysanthemi proteases) we have not yet been able to demonstrate cleavage of chromogenic substrates and have, therefore, been limited to the use of a multiply-cleaved proteinaceous substrate, BODIPY-FL-labelled casein, in our studies.

Here, we have presented the purification and initial characterization of the interaction of the Photorhabdus luminescens W14 inhibitor, Inh, with its cognate protease, PrtA. Further studies of the specific interactions between proteases of the repeats-in-toxin (RTX) zinc metalloprotease family and their cognate, or otherwise, inhibitors will provide more information about this unique mode of inhibition. Co-crystallization and structural analyses of the Photorhabdus luminescens W14 PrtA-Inh complex are currently being performed and these data will be reported elsewhere.

\section{ACKNOWLEDGEMENTS}

The authors would like to acknowledge the CNRS initiative 'Passion-Recherche', which enabled A.-C. Broutelle and M. Lefebvre to obtain their laboratory research experience. Our thanks are also due to Dr Philippe Minard for his assistance with the kinetic analyses and to Professor Pierre Le Marechal and Dr Paulette Decottignies for N-terminal-amino-acid sequencing and mass-spectrometry analysis.

\section{REFERENCES}

Ahn, J. H., Pan, J. G. \& Rhee, J. S. (1999). Identification of the tliDEF ABC transporter specific for lipase in Pseudomonas fluorescens SIK W1. J Bacteriol 181, 1847-1852.

Bae, K. H., Kim, I. C., Kim, K. S., Shin, Y. C. \& Byun, S. M. (1998). The Leu-3 residue of Serratia marcescens metalloprotease inhibitor is important in inhibitory activity and binding with Serratia marcescens metalloprotease. Arch Biochem Biophys 352, 37-43.

Baumann, U., Bauer, M., Letoffe, S., Delepelaire, P. \& Wandersman, C. (1995). Crystal structure of a complex between Serratia marcescens metallo-protease and an inhibitor from Erwinia chrysanthemi. J Mol Biol 248, 653-661.

Braunagel, S. C. \& Benedik, M. J. (1990). The metalloprotease gene of Serratia marcescens strain SM6. Mol Gen Genet 222, 446-451.

Brechtl, J. R., Breitbart, W., Galietta, M., Krivo, S. \& Rosenfeld, B. (2001). The use of highly active antiretroviral therapy (HAART) in patients with advanced HIV infection: impact on medical, palliative care, and quality of life outcomes. J Pain Symptom Manage 21, 41-51.

Burgos, F., Torres, A., Gonzalez, J., Puig de la Bellacasa, J., Rodriguez-Roisin, R. \& Roca, J. (1996). Bacterial colonization as a potential source of nosocomial respiratory infections in two types of spirometer. Eur Respir J 9, 2612-2617.

Chabeaud, P., de Groot, A., Bitter, W., Tommassen, J., Heulin, T. \& Achouak, W. (2001). Phase-variable expression of an operon encoding extracellular alkaline protease, a serine protease homolog, and lipase in Pseudomonas brassicacearum. J Bacteriol 183, 2117-2120.

Chen, G., Zhang, Y., Li, J., Dunphy, G. B., Punja, Z. K. \& Webster, J. M. (1996). Chitinase activity of Xenorhabdus and Photorhabdus species, bacterial associates of entomopathogenic nematodes. $J$ Invertebr Pathol 68, 101-108.

Dahler, G. S., Barras, F. \& Keen, N. T. (1990). Cloning of genes encoding extracellular metalloproteases from Erwinia chrysanthemi EC16. J Bacteriol 172, 5803-5815.

de Bentzmann, S., Polette, M., Zahm, J. M. \& 7 other authors (2000). Pseudomonas aeruginosa virulence factors delay airway epithelial wound repair by altering the actin cytoskeleton and inducing overactivation of epithelial matrix metalloproteinase-2. Lab Invest 80, 209-219.

Dubey, L., Krasinski, K. \& Hernanz-Schulman, M. (1988). Osteomyelitis secondary to trauma or infected contiguous soft tissue. Pediatr Infect Dis J 7, 26-34.

Duong, F., Lazdunski, A., Cami, B. \& Murgier, M. (1992). Sequence of a cluster of genes controlling synthesis and secretion of alkaline protease in Pseudomonas aeruginosa: relationships to other secretory pathways. Gene $121,47-54$.

Feltzer, R. E., Gray, R. D., Dean, W. L. \& Pierce, W. M., Jr. (2000). Alkaline proteinase inhibitor of Pseudomonas aeruginosa. Interaction of native and $\mathrm{N}$-terminally truncated inhibitor proteins 
with Pseudomonas metalloproteinases. J Biol Chem 275, 2100221009.

Fischer-Le Saux, M., Viallard, V., Brunel, B., Normand, P. \& Boemare, N. E. (1999). Polyphasic classification of the genus Photorhabdus and proposal of new taxa: P. luminescens subsp. luminescens subsp. nov., P. luminescens subsp. akhurstii subsp. nov., P. luminescens subsp. laumondii subsp. nov., P. temperata sp. nov., $P$. temperata subsp. temperata subsp. nov. and $P$. asymbiotica sp. nov. Int J Syst Bacteriol 49, 1645-1656.

Forst, S. \& Nealson, K. (1996). Molecular biology of the symbioticpathogenic bacteria Xenorhabdus spp. and Photorhabdus spp. Microbiol Rev 60, 21-43.

Forst, S., Dowds, B., Boemare, N. \& Stackebrandt, E. (1997). Xenorhabdus and Photorhabdus spp.: bugs that kill bugs. Annu Rev Microbiol 51, 47-72.

Gebbia, J. A., Coleman, J. L. \& Benach, J. L. (2001). Borrelia spirochetes upregulate release and activation of matrix metalloproteinase gelatinase B (MMP-9) and collagenase 1 (MMP-1) in human cells. Infect Immun 69, 456-462.

Guzzo, J., Murgier, M., Filloux, A. \& Lazdunski, A. (1990). Cloning of the Pseudomonas aeruginosa alkaline protease gene and secretion of the protease into the medium by Escherichia coli. J Bacteriol 172, 942-948.

Guzzo, J., Duong, F., Wandersman, C., Murgier, M. \& Lazdunski, A. (1991a). The secretion genes of Pseudomonas aeruginosa alkaline protease are functionally related to those of Erwinia chrysanthemi proteases and Escherichia coli $\alpha$-haemolysin. Mol Microbiol 5, 447-453.

Guzzo, J., Pages, J. M., Duong, F., Lazdunski, A. \& Murgier, M. (1991b). Pseudomonas aeruginosa alkaline protease: evidence for secretion genes and study of secretion mechanism. J Bacteriol 173, 5290-5297.

Hammond, S. E. \& Hanna, P. C. (1998). Lethal factor active-site mutations affect catalytic activity in vitro. Infect Immun 66, 2374-2378.

Hanna, P. (1999). Lethal toxin actions and their consequences. $J$ Appl Microbiol 87, 285-287.

Hege, T., Feltzer, R. E., Gray, R. D. \& Baumann, U. (2001). Crystal structure of a complex between Pseudomonas aeruginosa alkaline protease and its cognate inhibitor: inhibition by a zinc- $\mathrm{NH}_{2}$ coordinative bond. J Biol Chem 276, 35087-35092.

Herouy, Y. (2001). Matrix metalloproteinases in skin pathology (Review). Int J Mol Med 7, 3-12.

Hsueh, P. R., Teng, L. J., Pan, H. J., Chen, Y. C., Sun, C. C., Ho, S. W. \& Luh, K. T. (1998). Outbreak of Pseudomonas fluorescens bacteremia among oncology patients. J Clin Microbiol 36, 2914-2917.

Hynes, W. L., Dixon, A. R., Walton, S. L. \& Aridgides, L. J. (2000). The extracellular hyaluronidase gene (bylA) of Streptococcus pyogenes. FEMS Microbiol Lett 184, 109-112.

Kawai, E., Idei, A., Kumura, H., Shimazaki, K., Akatsuka, H. \& Omori, K. (1999). The ABC-exporter genes involved in the lipase secretion are clustered with the genes for lipase, alkaline protease, and serine protease homologues in Pseudomonas fluorescens no. 33. Biochim Biophys Acta 1446, 377-382.

Kling, J. J., Wright, R. L., Moncrief, J. S. \& Wilkins, T. D. (1997). Cloning and characterization of the gene for the metalloprotease enterotoxin of Bacteroides fragilis. FEMS Microbiol Lett 146, 279-284.

Laemmli, U. K. (1970). Cleavage of structural proteins during the assembly of the head of bacteriophage T4. Nature 227, 680-685.

Letoffe, S., Delepelaire, P. \& Wandersman, C. (1989). Characteri- zation of a protein inhibitor of extracellular proteases produced by Erwinia chrysanthemi. Mol Microbiol 3, 79-86.

Letoffe, S., Delepelaire, P. \& Wandersman, C. (1990). Protease secretion by Erwinia chrysanthemi: the specific secretion functions are analogous to those of Escherichia coli $\alpha$-haemolysin. EMBO J 9, 1375-1382.

Letoffe, S., Delepelaire, P. \& Wandersman, C. (1991). Cloning and expression in Escherichia coli of the Serratia marcescens metalloprotease gene: secretion of the protease from E. coli in the presence of the Erwinia chrysanthemi protease secretion functions. J Bacteriol 173, 2160-2166.

Liao, C. H. \& McCallus, D. E. (1998). Biochemical and genetic characterization of an extracellular protease from Pseudomonas fluorescens CY091. Appl Environ Microbiol 64, 914-921.

Maniatis, T., Fritsch, E. F. \& Sambrook, J. (1982). Molecular Cloning: a Laboratory Manual. Cold Spring Harbor, NY: Cold Spring Harbor Laboratory.

Marits, R., Koiv, V., Laasik, E. \& Mae, A. (1999). Isolation of an extracellular protease gene of Erwinia carotovora subsp. carotovora strain SCC3193 by transposon mutagenesis and the role of protease in phytopathogenicity. Microbiology 145, 1959-1966.

Moncrief, J. S., Obiso, R., Jr, Barroso, L. A., Kling, J. J., Wright, R. L., Van Tassell, R. L., Lyerly, D. M. \& Wilkins, T. D. (1995). The enterotoxin of Bacteroides fragilis is a metalloprotease. Infect Immun 63, 175-181.

Nakahama, K., Yoshimura, K., Marumoto, R., Kikuchi, M., Lee, I. S., Hase, T. \& Matsubara, H. (1986). Cloning and sequencing of Serratia protease gene. Nucleic Acids Res 14, 5843-5855.

Olson, J. C. \& Ohman, D. E. (1992). Efficient production and processing of elastase and LasA by Pseudomonas aeruginosa require zinc and calcium ions. J Bacteriol 174, 4140-4147.

Ong, K. L. \& Chang, F. N. (1997). Analysis of proteins from different phase variants of the entomopathogenic bacteria Photorhabdus luminescens by two-dimensional zymography. Electrophoresis 18, 834-839.

Peel, M. M., Alfredson, D. A., Gerrard, J. G., Davis, J. M., Robson, J. M., McDougall, R. J., Scullie, B. L. \& Akhurst, R. J. (1999). Isolation, identification, and molecular characterization of strains of Photorhabdus luminescens from infected humans in Australia. J Clin Microbiol 37, 3647-3653.

Poyart, C., Abachin, E., Razafimanantsoa, I. \& Berche, P. (1993). The zinc metalloprotease of Listeria monocytogenes is required for maturation of phosphatidylcholine phospholipase C: direct evidence obtained by gene complementation. Infect Immun 61, 1576-1580.

Raveneau, J., Geoffroy, C., Beretti, J. L., Gaillard, J. L., Alouf, J. E. \& Berche, P. (1992). Reduced virulence of a Listeria monocytogenes phospholipase-deficient mutant obtained by transposon insertion into the zinc metalloprotease gene. Infect Immun 60, 916-921.

Tonello, F., Morante, S., Rossetto, O., Schiavo, G. \& Montecucco, C. (1996). Tetanus and botulism neurotoxins: a novel group of zinc-endopeptidases. Adv Exp Med Biol 389, 251-260.

Travis, J. \& Potempa, J. (2000). Bacterial proteinases as targets for the development of second-generation antibiotics. Biochim Biophys Acta 1477, 35-50.

Vehmaan-Kreula, P., Puolakkainen, M., Sarvas, M., Welgus, H. G. \& Kovanen, P. T. (2001). Chlamydia pneumoniae proteins induce secretion of the $92-\mathrm{kDa}$ gelatinase by human monocyte-derived macrophages. Arterioscler Thromb Vasc Biol 21, E1-8.

Wang, H. \& Dowds, B. C. (1993). Phase variation in Xenorhabdus luminescens: cloning and sequencing of the lipase gene and 
analysis of its expression in primary and secondary phases of the bacterium. J Bacteriol 175, 1665-1673.

Wee, K. E., Yonan, C. R. \& Chang, F. N. (2000). A new broadspectrum protease inhibitor from the entomopathogenic bacterium Photorhabdus luminescens. Microbiology 146, 3141-3147.

Welch, R. A. (1991). Pore-forming cytolysins of Gram-negative bacteria. Mol Microbiol 5, 521-528.

Yoshihara, K., Matsushita, O., Minami, J. \& Okabe, A. (1994).

Cloning and nucleotide sequence analysis of the colH gene from
Clostridium histolyticum encoding a collagenase and a gelatinase. J Bacteriol 176, 6489-6496.

Zhang, Y., Bak, D. D., Heid, H. \& Geider, K. (1999). Molecular characterization of a protease secreted by Erwinia amylovora. J Mol Biol 289, 1239-1251.

Received 11 February 2002; revised 16 April 2002; accepted 22 April 2002. 